\title{
Efektifitas Pelayanan Pengujian Kendaraan Bermotor Berkala di Dinas Pehubungan Kabupaten Subang
}

\author{
Silvy Sondari ${ }^{1}$ \\ Fakultas Ilmu Administrasi Universitas Subang \\ silvysondari.gadzali@gmail.com \\ Ade Suparman ${ }^{2}$ \\ Fakultas Ilmu Administrasi Universitas Subang \\ suparmanade09@gmail.com
}

\begin{abstract}
Abstrak
Hasil penelitian menunjukan bahwa Efektivitas Pelayanan Pengujian Kendaraan Bermotor Berkala di Dinas Perhubungan Kabupaten Subang dinilai belum efektif dikarenakan : 1) kondisi petugas pengujian kendaraan bermotor belum efektif hal ini dilihat dari belum adanya teknisi atau petugas yang bisa memperbaiki alat/mesin uji kendaraan. 2) partisipasi petugas pengujian kendaraan bermotor belum efektif hal ini dapat dilihat dari belum adanya rapat terbuka yang mengundang masyarakat dan seluruh stakeholder untuk menyampaikan aspirasinya. 3) kesamaan hak yang di berikan petugas pengujian kendaraan bermotor belum efektif hal ini dapat dilihat dari perbedaan hak yang didapat berdasarkan status sosial dan kedekatan pihak dalam.
\end{abstract}

Kata Kunci : Efektivitas, Pelayanan, Pengujian Kendaraan Bermotor

\begin{abstract}
The results showed that the effectiveness of the Periodic Motorized Vehicle Testing Service in the Subang District Transportation Office is considered not effective because : 1) The condition of the motor vehicle testing officer has not been effective as seen from the absence of a technician or an officer who can repair vehicle testing equipment / machines. 2) The participation of the motor vehicle testing officer is not yet effective, it can be seen from the absence of an open meeting that invites the public and all stakeholders to express their aspirations. 3) The equality of rights granted by motorized vehicle testing officers has not been effective yet, this can be seen from the difference in rights obtained based on social status and proximity of an insider.
\end{abstract}

Keywords: Effectiveness, Service, Motor Vehicle Testing. 


\section{Pendahuluan}

Pelayanan merupakan tugas utama bagi aparatur negara sebagai abdi negara dan abdi masyarakat. Tugas ini secara jelas telah digariskan dalam Undang-undang dasar 1945 alinea ke empat, yang meliputi empat aspek pelayanan pokok aparatur terhadap masyarakat yang berbunyi : Melindungi segenap bangsa dan seluruh tumpah darah Indonesia memajukan kesejahteraan umum dan mencerdaskan kehidupan bangsa. Untuk mengevaluasi jalannya suatu organisasi, dapat dilakukan upaya melalui konsep efektivitas yang menekankan pada pencapaian tujuan yang telah ditetapkan sebelumnya. Tingkat efektivitas dapat diukur dengan membandingkan rencana atau target yang telah ditentukan dengan hasil yang dicapai, apabila rencana atau target yang telah ditentukan tidak tercapai sesuai dengan rencana maka hal itu dikatan tidak efektif, karena pada dasarnya kata efektif sangat erat kaitannya dengan waktu. Dalam hal ini efektivitas merupakan pemanfaatan sumberdaya, sarana dan prasarana dalam jumlah tertentu yang secara sadar ditetapkan sebelumnya untuk menghasilkan sejumlah pekerjaan tepat pada waktunya ( Abdurahmat dalam Othenk 2008 : 7). Pelayanan masyarakat dapat dikategorikan efektif apabila masyarakat mendapat kemudahan pelayanan dengan prosedur yang singkat, tepat, cepat, dan memuaskan. Keberhasilan meningkatkan efektivitas pelayanan umum dapat ditentukan oleh faktor kemampuan pemerintah dalam meningkatkan disiplin kerja aparat pelayanan .

Membangun kepercayaan masyarakat atas pelayanan publik yang dilakukan penyelenggara pelayanan publik merupakan kegiatan yang harus dilakukan seiring dengan harapan dan tuntutan seluruh warga negara dan penduduk tentang peningkatan pelayanan publik, sebagai upaya untuk mempertegas hak dan kewajiban setiap warga negara dan penduduk serta terwujudnya tanggung jawab negara dan korporasi dalam penyelenggaraan pelayanan publik, diperlukan norma hukum yang memberi pengaturan secara jelas, sebagai upaya untuk meningkatkan kualitas dan menjamin penyediaan pelayanan publik sesuai dengan asas-asas umum pemerintahan dan korporasi yang baik serta untuk memberi perlindungan bagi setiap warga negara dan penduduk dari penyalahgunaan wewenang di dalam penyelenggaraan pelayanan public.

Salah satu pelayanan bagi masyarakat dari pemerintahan adalah pelayanan pengujian kendaraan bermotor di Dinas Perhubungan yang di landasi undang-undang no.22 tahun 2009 tentang Lalu Lintas Angkutan Jalan dan Peraturan Mentri Perhubungan No. 98 tahun 2013 tentang SPM (standar pelayanan minimal) angkutan orang. Dalam era globalisasi dengan kondisi persaingan yang cukup ketat dan penuh tantangan aparatur pemerintahan dituntut untuk memberikan pelayanan sebaikbaiknya kepada masyarakat. Efektivitas pelayanan ini menjadi salah satu indicator dari tingkat keberhasilan pemerintah dalam menjalankan suatu kegiatan organisasi yang sesuai dengan proses tujuan, Dinas Perhubungan Kabupaten Subang bidang Pengujian Kendaraan Bermotor yaitu menguji kendaraan angkutan roda empat dengan tahap tahap tertentu. 
Pengujian kendaraan bermotor disebut juga uji KIR adalah serangkaian kegiatan menguji dan atau memeriksa bagian-bagian kendaraan bermotor, kereta gandengan, kereta tempelan dan kendaraan khusus dalam rangka pemenuhan terhadap persyaratan teknis dan layak jalan, Pelaksanaan Pengujian Kendaraan Bermotor di Unit PKB dan pemeriksaan dilakukan oleh Penguji yang memenuhi persyaratan yang ditetapkan oleh pemerintah, bagi kendaraan yang memenuhi kelaykan akan disahkan oleh pejabat lalu akan diberi tanda uji. Keselarasan antara pengguna angkutan umum dan penyedia angkutan umum idealnya harus baik dan benar untuk mewujudkan keamanan, keselamatan, ketertiban dan kelancaran berlalu lintas. Pasal 48 hingga Pasal 55 Undang-Undang No. 22 Tahun 2009 tentang Lalu Lintas dan Angkutan Jalan, telah menetapkan persyaratan teknis dan layak jalan kendaraan bermotor serta mewajibkan kendaraan bermotor yang diimpor, dibuat dan dirakit di dalam negeri yang akan dioperasikan di jalan wajib dilakukan pengujian berkala kendaraan bermotor yang selanjutnya di sebut (KIR). Sehingga kendaraan umum baik angkot, bus, maupun kendaraan barang, kereta gandengan, kereta tempelan yang dioperasikan di jalan umum wajib hukumnya untuk mematuhi peraturan yang berlaku dalam pengoperasiannya dan salah satu persyaratan sistem transportasi publik adalah harus mendapatkan pengujian bahwa kendaraan tersebut layak secara berkala sehingga layak untuk dipakai dan dituangkan dalam buku KIR pemilik kendaraan umum yang tidak di tes uji layak beroprasi dan belum adanya Saat ini Bidang Pengujian Kendaraan Bermotor di Dinas Perhubungan Kabupaten Subang masih mempunyai permasalahan yaitu bagaimana cara menghadapi pemberitahuan bentuk SMS gateaway kepada pemilik kendaraan yang isi di dalamnya berupa pemberitahuan kendaraan untuk melukan uji layak kendaraan berkala atau selanjutnya selama 6 bulan kemudian lalu permasalahan adanya ketidaksamaan hak dan waktu yang di berikan oleh petugas penguji kendaraan bermotor pada pemilik kendaraan yang akan di uji melalui perantara/calo.

Tabel 1

Data jumlah pemohon KIR melalui calo di Dinas Perhubungan Subang

\begin{tabular}{|c|c|c|c|}
\hline \multirow{2}{*}{ No } & Bulan & Jumlah KIR Kendaraan & Keterangan \\
\hline 1 & Januari & 1272 kendaraan & $41,17 \%$ \\
\hline 2 & Februari & 1130 kendaraan & $35,93 \%$ \\
\hline 3 & Maret & 1192 kendaraan & $11,92 \%$ \\
\hline 4 & April & 1131 kendaraan & $9,82 \%$ \\
\hline 5 & Mei & 1253 kendaraan & $16,63 \%$ \\
\hline 6 & Juni & 837 kendaraan & $7,81 \%$ \\
\hline 7 & Juli & 1462 kendaraan & $11,88 \%$ \\
\hline 8 & Agustus & 1259 kendaraan & $11,83 \%$ \\
\hline 9 & September & 1222 kendaraan & $39,16 \%$ \\
\hline 10 & Oktober & 1437 kendaraan & $48,83 \%$ \\
\hline
\end{tabular}




\begin{tabular}{|l|c|c|c|}
\hline 11 & November & 1391 kendaraan & $10,54 \%$ \\
\hline 12 & Desember & 1176 kendaraan & $29,95 \%$ \\
\hline
\end{tabular}

Sumber data : Dinas Perhubungan Subang 2018

Berdasarkan hasil penelitiann pada Dinas Perhubungan bidang Pengujian Kendaraan Bermotor di Kabupaten Subnag belum optimal hal ini dapat di lihat bahwa akuntabilitas, tidak adanya sistem pemberitahuan kepaada pemilik kendaraan berbentuk SMS gateaway yang di dalamnya pemberitahuan mengenai pengujian kendaraan bermotor berkala untuk selanjutnya serta kesamaan hak, dalam Dinas Perhubungan Kabupaten Subang 22,96\% bidang Pengujian Kendaraan Bermotor di kuasai oleh para calo. Hal ini menunjukkan bahwa dalam tata kelola pelayanan belum efektif.

\section{Kerangka Teori}

\section{a. Pengertian Efektivitas}

Efektivitas berasal dari kata efektif yang berarti terjadinya suatu efek atau akibat yang di hendaki dalam sesuatu perbuatan (Ensiklopedi Administrasi, 1989: 149). Efektif dalam Kamus Besar Bahasa Indonesia berarti dapat membawa hasil, berhasil guna. Sedangkan menurut Handoko (1993: 7) efektivitas adalah kemampuan untuk memilih tujuan yang tepat atau peralatan yang tepat untuk mencapai tujuan yang telah ditetapkan. Dalam kenyataannya, sulit sekali merinci apa yang dimaksud dengan konsep efektivitas dalam suatu organisasi. Pengertian efektivitas dalam suatu organisasi mempunyai arti yang berbedabeda bagi setiap orang, bergantung pada kerangka acuan yang dipakainya. Bagi sejumlah sarjana ilmu administrasi, efektivitas adalah tingkat keberhasilan suatu kinerja organisasi dalam mencapai tujuan. Richard M. Steers (1985: 1) mengemukakan bahwa pada dasarnya cara yang terbaik untuk meneliti efektivitas ialah dengan memperhatikan secara serempak tiga buah konsep yang saling berhubungan yaitu : a) Paham mengenai optimasi tujuan : efektivitas dinilai menurut ukuran seberapa jauh sebuah organisasi berhasil mencapai tujuan yang layak dicapai; b) Perspektif sistematika : tujuan mengikuti suatu daur dalam organisasi; dan c) Tekanan pada segi perilaku manusia dalam susunan organisasi : bagaimana tingkah laku individu dan kelompok akhirnya dapat menyokong atau menghalangi tercapainya tujuan organisasi (Steers, 1985:4-7) . Georgepoulus Tenenbaum (Richard M. Steers, 1985:20) berpendapat bahwa konsep efektivitas kadang-kadang disebut sebagai keberhasilan yang biasanya digunakan untuk menunjukan pencapaian tujuan. Sangat jelas dalam suatu organisasi efektivitas adalah keadaan yang oleh organisasi di perjuangkan untuk di capai. Menurut Emerson dalam Handayaningrat (1985:16 : 19) definisi lain yang dapat dijadikan acuan adalah Efektivitas ialah pengukuran dalam arti tercapainya sasaran atau tujuan yang telah ditentukan sebelumnya. Jelaslah bila sasaran uji KIR telah tercapai sesuai dengan aturan yang tertera, hal ini 
dikatakan efektif. Jadi apabila tujuan atau sasaran tidak sesuai dengan yang telah ditentukan, maka pekerjaan itu dikatakan tidak efektif. Efektivitas pelayanan publik merupakan pengukuran dalam arti tercapainya sasaran dan tujuan yang telah ditemukan sebelumnya. Menurut Emerson yang dikutip oleh Soewarno (1996:16) Sedangkan Sondang P. Siagian (1997:151), “Efektivitas pelayanan publik berarti penyelesaian pekerjaan tepat pada waktu yang telah ditentukan, artinya pelaksanaan sesuatu tugas dinilai baik atau tidak sangat tergantung pada penyelesaian tugas tersebut dengan waktu yang telah ditetapkan".

\section{b. Pengertian pelayanan}

Pengertian pelayanan umum atau pelayanan public tidak terlepas dari masalah-masalah kepentingan umum. Kepentingan umum dan pelayanan umum saling berkaitan. Pelayanan public dalam perkembanganya dapat juga timbul karena adanya kewajiban suatu proses penyelenggaraan kegiatan pemerintah dan organisasi. Maupun pelayanan adalah segala bentuk jasa, baik dalam bentuk barang publik maupun jasa publik yang pada prinsipnya menjadi tanggung jawab dan dilaksanakan oleh instansi pemerintah di pusat, di daerah, dan di lingkungan Badan Usaha Milik Negara atau Badan Usaha Milik Daerah, dalam rangka upaya pemenuhan kebutuhan masyarakat maupun dalam rangka pelaksanaan ketentuan peraturan perundang-undangan. Pengertian pelayanan publik menurut Dwiyanto (2006:136) pelayanan public adalah serangkaian aktivitas yang dilakukan oleh birokrasi public, untuk memenuhi kebutuhan warga negara pengguna. Berdasarkan definisi di atas, pengguna yang di maksud disisna yaitu pemilik kendaraan yang akan di uji layak kendaran yang membutuhkan surat keterangan layak berkendara dan tanggal uji layak selanjutnya agar pengujian kendaran di lakukan berkala. Jadi arti pelayanan publik adalah salah satu cara dari pemerintah atau pemberi pelayanan dalam memenuhi kebutuhan masyarakat atau penerima pelayanan. Sedangkan keputusan Mentri Pendayagunaan Apatur Negara nomor 63 tahun 2003, definisi dari pelayanan umum adalah segala bentuk pelayanan yang dilaksanakan oleh nstansi pemerintah di pusat atau di daerah, dan di lingkungan badan usaha milik negara atau badan usaha milik daerah dalam bentuk barang dan jasa, baik dalam rangka pelaksanaan ketentuan perundang-undangan. Mengikuti definisi diatas, pelayanan publik atau pelayanan umum dapat di definisikan sebagai segala bentuk jasa pelayanan, baik dalam bentuk barang maupun jasa publik yang pada prinsipnya menjadi tanggung jawab dan dilaksanakan oleh intansi pemerintah pusat di daerah dan di lingkungan Badan Usaha Milik Negara atau Badan Usaha Milik Daerah dalam upaya pemenuhan ketentuan perundangundangan (Ratminto dan Atik Septi Winarsih,2007:4-5). Pelayanan umum atau pelayanan publik menurut Sadu Wasisrtiono (2005:51-52) adalah pemberian jasa baik oleh pemerintah, pihak swasta atas nama pemerintah ataupun pihak swasta kepada masyarakat. Dalam definisi ini pelayanan publk diatrikan sebagai 
pemberian jasa dari pemerintah kepada masyarakat guna memenuhi kepentingan masyrakat dengan atau tanpa pembayaran.

Dari beberapa pengertian di atas yang telah diuraikan dalam konteks pemerintahan daerah pelayanan publik dapat disimpulkan sebagai pemberi layanan atau melayani keperluan orang atau masyarakat dana atau organisasi lain yang mempunyai kepentingan pada organisasi itu sesuai dengan aturan pokok dan tata cara yang di tentukan dan di untukan untuk memberikan kepuasan kepada penerima pelayanan. Menurut Ridwan dan Sudrajat (2009:19) pelayanan publik merupakan pelayanan yang diberikan oleh pemerintah sebagai penyelenggara negara terhadap masyarakat nya guna memenuhi kebutuhan dari masyarakat itu sendiri dan memiliki tujuan untuk meningkatkan kesejahteraan masyarakat. Jadi pemerintah menyediakan pelayanan yang baik dengan melakukan pengujian kendaraan bermotor bertujuan untuk mengurangi jumlah kecelakaan kendaraan muatan dan kendaraan umum. Hall dalam Tangkilisan (2005:67) mengartikan bahwa dengan tingkat sejauh mana suatu organisasi merealisasikan tujuannya, semua konsep tersebut hanya menunjukkan pada pencapaian tujuan organisasi. Sedangkan bagaimana cara mencapainya tidak dibahas. Yang membahas bagaimana mencapai tingkat efektivitas adalah Argris dalam Tangkilisan (2005:68) yang mengatakan "Organizational effectiveness then is balanced organization optimal emphasis upon achieving object solving competence and human energy utilization" atau dengan kata lain efektivitas organisasi adalah keseimbangan atau pendekatan secara optimal pada pencapaian tujuan, kemampuan dan pemanfaatan tenaga manusia. Amirullah dan Ribdyah Hanafi (2002) efektivitas menunjukkan kemampuan suatu perusahaan dalam mencapai sasaran yang telah ditetapkan secara tepat. Pencapaian sasaran yang telah ditetapkan dan ukuran maupun standar yang berlaku mencerminkan suatu perusahaan tersebut telah memperhatikan efektivitas operasionalnya.

\section{c. Standar Pelayanan Publik}

Menurut Ridwan dan Sudrajat (2009:103) setiap penyelenggaraan pelayanan publik harus memiliki standar pelayanan dan dipublikasikan sebagai jaminan adanya kepastian bagi penerima pelayanan. Standar pelayanan adalah ukuran yang diberlakukan dalam peyelenggaraan pelayanan yang wajib ditaati oleh pemberi dan atau penerima pelayanan. adapun standar pelayanan yakni meliputi sebagai berikut:

1) Prosedur pelayanan

2) Prosedur pelayanan yang dibakukan bagi pemberi dan penerima pelayanan termasuk pegaduan.

3) Waktu peyelesaian

4) Waktu penyelesaian yang ditetapkan sejak saat pengajuan permohonan sampai dengan penyelesaian pelayanan termasuk pengaduan.

5) Biaya pelayanan 
6) Biaya atau tarif pelayanan termasuk rincian yang ditetapkan dalam proses pemberian pelayanan.

7) Produk pelayanan

8) Hasil pelayanan yang akan diterima sesuai dengan ketentuan yang telah ditetapkan.

9) Sarana dan prasarana

10) Penyedian sarana dan prasarana pelayanan yang memadai oleh penyelenggaraan pelayanan publik.

11) Kompetensi petugas pemberi pelayanan

Kompetensi petugas pemberi pelayanan harus ditetapkan dengan tepat berdasarkan pengetahuan, keahlian, keterampilan, sikap, dan perilaku yang dibutuhkan. Sedangkan standar pelayanan menurut Kasmir (2005: 18-21) yaitu dasar-dasar pelayanan terdapat sepuluh hal yang harus diperhatikan agar dapat membuat penerima layanan menjadi aman, nyaman, dan menyenangkan, antara lain seperti : Berpakaian dan berpenampilan rapi dan bersih, Percaya diri, bersikap akrab dan penuh dengan senyuman, dan menyapa dengan lembut dan berusaha menyebutkan nama jika sudah mengenal satu sama lain.

1) Tenang, sopan, hormat, serta tekun mendengarkan sikap pembicaraan.

2) Berbicara dengan bahasa yang baik dan benar.

3) Bergairah dalam melayani nasabah dan menunjukkan kemampuannya.

4) Jangan menyela atau memotong pembicaraan.

5) Mampu meyakinkan nasabah serta memberikan kepuasan.

6) Jika tidak sanggup menangani permasalahan yang ada, minta bantuan.

7) Bila belum dapat melayani, beritahu kapan akan dilayani.

Berdasarkan pemaparan di atas dapat disimpulkan bahwa penyusunan standar pelayanan publik tersebut dapat dipakai sebagai pedoman dan pelayanan public oleh intansi pemerintah. Dengan adanya standar pelayanan publik ini diharapkan masyarakat bisa mendapatkan pelayanan yang sesuai dengan kebutuhan dan proses yang memuaskan serta tidak menyulitkan masyarakat. kriteria pelayanan yang dikemukakan oleh Sinambela (2010:6) ada enam dimensi untuk mengukur pelayanan pada sektor publik, yaitu : Transparansi, Akutabilitas, Kondisional, Partisipatif, Kesamaan Hak, serta Keseimbangan hak dan kewajiban.

1) Transparansi adalah keterbukaan atas semua tindakan dan kebijakan yang diambil oleh pemerintah. Prinsip transparansi menciptakan kepercayaan timbal-balik antara pemerintah dan masyarakat melalui penyediaan informasi dan menjamin kemudahan di dalam memperoleh informasi yang akurat dan memadai.

2) Akuntabilitass adalah pertangungjawaban pejabat publik terhadap masyarakat yang memberinya kewenangan untuk mengurusi kepentingan mereka. Para pengambil keputusan di pemerintah, sektor swasta dan organisasi-organisasi masyarakat bertanggung jawab baik kepada masyarakat maupun kepada lembaga-lembaga yang berkepentingan. Bentuk 
pertanggungjawaban tersebut berbeda satu dengan lainnya tergantung dari jenis organisasi yang bersangkutan. Instrumen dasar akuntabilitas adalah peraturan perundang-undangan yang ada, dengan komitmen politik akan akuntabilitas maupun mekanisme pertanggungjawaban, sedangkan instrumen-instrumen pendukungnya adalah pedoman tingkah laku dan sistem pemantauan kinerja penyelenggara pemerintahan dan sistem pengawasan dengan sanksi yang jelas dan tegas.

3) Kondisional adalah suatu keadaan dimana penyesuaian dengan kondisi yang sedang di alami sesuai dengan kondisi dan kemampuan pemberi dan penerima pelayanan dengan tetap berpegang pada prinsip efisiensi dan efektifitas.

4) Partisipasi berasal dari bahasa inggris yaitu "participation" adalahpengambilan bagian atau pengikutsertaan. Menurut Keith Davis, partisipasi adalah suatu keterlibatan mental dan emosi seseorang kepada pencapaian tujuan dan ikut bertanggung jawab di dalamnya.

5) Kesamaan Hak yaitu tidak diskriminatif dalam arti tidak membedakan suku, ras, dan agama, golongan, gender dan status ekonomi.

6) Keseimbangan Hak dan Kewajiban yaitu seimbangnya antara hak dan kewajiban dimana kita tidak boleh terus-menerus menuntut hak tanpa melakukan kewajiban kita dan tidak boleh terus menyuruh yang lain melakukan kewajibannya tanpa kita memberikan haknya.

\section{Metode Penelitian}

Metode penelitian yang digunakan dalam penelitian ini adalah pendekatan kualitatif. Menurut Creswell (2010: 4) penelitian kualitatif merupakan metode yang digunakan untuk mengeksplorasi dan memahami makna yang oleh sejumlah individu atau sekelompok orang dianggap berasal dari masalah sosial atau kemanusiaan. Proses penelitian ini melibatkan upaya-upaya penting seperti mengajukan pertanyaanpertanyaan dan prosedur-prosedur mengumpulkan data spesifik dari partisipan, menganalisis data secara induktif melalui tema-tema yang khusus ke tema-tema yang umum, dan menafsirkan makna dari data.

Tujuan utama penelitian kualitatif adalah untuk memahami fenomena atau gejala sosial dengan lebih menitik beratkan pada gambaran yang lengkap tentang fenomena yang dikaji dari pada memerincinya menjadi variabel-variabel yang saling terkait. Harapannya ialah diperoleh pemahaman yang mendalam tentang fenomena untuk selanjutnya dihasilkan. Adapun alasan pemilihan metode kualitatif adalah untuk mendalami proses pelaksanaan Pengujian Kendaraan Bermotor berkala yang kemudian dilakukan evaluasi untuk mengetahui faktor-faktor penyebab kegagalan dan kemudian dijadikan dasar bagi pelaksana kebijakan untuk melaksanakan kembali program agar tidak melakukan kesalahan yang sama. 
Volume 1 Issue 2, Desember 2019

https:// ejournal.unsub.ac.id/index.php/publik

\section{Hasil dan Pembahasan}

\section{a. Gambaran Umum Dinas Perhubungan Kabupaten Subang}

Sejak pemerintah Hindia Belanda, sektor transportasi khususnya lalulintas jalan di tangani oleh Department Weg Verkeer en Water Staat (Departemen Lalu Lintas dan Pengairan Negara) sebagai aturan hukum dan pelaksanaanya tercantum dalam Weg Verkeer Ordonantie (WVO) Staat Blad Nomor : 86 tahun 1933.

Pada tahun 1942 samai tahun 1945 dpartemen yang mengatur lalu lintas tidak berfungsi secara maksimal, hal ini karena alasan politis serta kndisi pemerintahan pada saat itu dalam situasi perang kemerdekaan, kemudian baru aktif kembali pada tahun 1950 dan berada pada Departemen Lalu Lintas dan Pengairan Negara.

Pada tahun 1957 indonesia mengeluakan Undang-Undang nomor 1 : tahun 1957 tentang pokok-pokok pemerintahan di daerah, dengan berpedoman pada Undang-Undang ini8 pemerintah memberikan kebijakan untuk menyerahkan sebagian urusan lalu lintas kepada pemerintah daerah tingkat 1, atas dasar tersebut daerah-daerah yang diserahi urusan lalu lintas untuk membentuk jawatan lalu lintas jalan. Dengan lahirnya Peraturan Pemerintah nomor 16 tahun 1958 akhirnya Undang-Undang WVO pada tanggal 1 April 1965 dinyatakan tidak berlaku kemudian pemerintah mengesahkan Unang-Undang tersebut di ganti dengan Nomor 3 tahun 1965 tentang Lalu Lintas dan Angkutan Jalan Raya. Pada tanggal 23 juli 1974 pemerintah mengesahkan Undang-Undang Nomor 5 tahun 1974 tentang pokok-pokok pemerintahan di daerah. Pemerintah daerah Tk. I Jawa Barat mengeluarkan Perda Nomor 2/PO.040/PD/78 tentang Susunan Organisasi dan Tata Kerja Dinas LLAJ Provinsi Daerah Tk. I Jawa Barat untuk cabang Dinas Lalu Lintas dan Angkutan Jalan Raya diatur dengan Peraturan Daerah Tk. I Jawa Barat Nomor 8 tahun 1984. Bertolak dari otonomi daerah tingkat I dan daerah tingkat II pemerintah RIS tingkat III, mengeluarkan Peraturan Pemerintah Nomor 22 tahun 1990 tentang penyerahan sebagian urusan Lalu Lintas dan Angkutan Jalan kepada daerah tingkat I dan daerah tingkat II. Tindak lanjut dari PP no 22 tahun 1990 keluarlah Keputusan Bersama Mentri Perhubungan dan Mentri Dalam Negri KM 109 tahun 1990 no 95 tahun 1990 mengenai Pelaksanaan Peraturan Pemerintah tersebut, peyerahan sebagian urusan Lalu Lintas dan Angkutan Jalan kepda daerah tingkat I dan daerah tingkat II berdasarkan PP ini pula lahirnya istilah Lalu Lintas dan Angkutan Jalan. Berdasarkan Undang-Undang Nomer 22 tahun 1999 tentang pemerintahan daerah, Peraturan Pemerintah Nomer 25 tahun 2000 tentang Kewenangan dan Provinsi sebagai daerah Otonomi, Peraturan Daerah Kabupaten Subang Nomor 26 tahun 2000 tentang pembentukan organisasi Dinas Daerah Lingkugan Kabupaten Subang, maka Dinas Perhubungan Kabupaten 
Subang sesuai dengan surat Keputusan Bupati Subang Nomer 28 thun 2001 tentan Tugas Pokok dan Pungsi Dinas Perubungan Kabupaten Subang, dan terakhi diubah dengan Peraturan Daerah Nomer 7 tahun 2008 Tentang Organisasi dan Tata Kerja. Visi jangka panjang Kabupaten Subang tahun 20052025 adalah :

“Terwujudnya Kabupaten Subang sebagai Daerah Agribisnis, Pariwisata dan Industri yang Berwawasan Lingkungan dan Religius serta Berbudaya melalui Pembangunan Berbasis Gotong Royong pada Tahun 2025." Sedangkan visi jangka menengah Kabupaten Subang tahun 2014-2018 adalah: "Terwujudnya Kabupaten Subang yang Religius, Berilmu, Mandiri, Berbudaya dan Bergotong Royong." Berdasarkan Visi Pemerintah Kabupaten Subang tersebut, maka Visi Dinas Perhubungan Kabupaten Subang yang ditetapkan adalah: "Tercapainya Sistem Pengujian Kendaraan Bermotor yang Bekualitas dan Akuntabel." Visi tersebut mempunyai maksud sebagai berikut: Sistem Pengujian Kendaraan Bermotor berkala di Dinas perhubungan Kabupaten Subang ingin menciptakan citra positif terhadap seluruh element masyarakat dan stakeholder dengan proses yang berkualitas dan dapat di pertanggungjawabkan. Untuk mewujudkan visi tersebut, maka Dinas Perhubungan Kabupaten Subang telah menetapkan misi sebagai berikut:

1) Meningkatkan kompetensi pengujiyang handal, berkualitas dan profesional

2) Melakukan perbaikan sarana dan prasarana secara berkelanjutan

3) Menciptakan sistem kerja yang efektif dan efisien

4) Menciptakan lingkungan kerja yang lebih kondusif dalam rangka meningkatkan mutu pelayanan

\section{b. Efektivitas Pelayanan Pengujian Kendraan Bermotor Berkala di Dinas Perhubungan Kabupaten Subang}

Sebagaimana yang telah dijelaskan pada bab pendahuluan, penelitian ini dilaksanakan untuk mengkaji tentang bagaimana efektivitas pelayanan Pengujian Kendaraan Bermotor Berkala yang telah dilaksanakan oleh pemerintah kabupaten subang melalui dinas perhubungan dengan menganalisa menggunakan kriteria pelayanan yang dikemukakan oleh Sinambela (2010:6) ada enam dimensi untuk mengukur pelayanan pada sektor publik, yaitu : Transparansi, Akutabilitas, Kondisional, Partisipatif, Kesamaan Hak, serta Keseimbangan hak dan kewajiban.

Hasil penelitian terhadap kriteria "Transparansi" dapat dijelaskan sebagai berikut : bahwa Transparansi merupakan Keterbukaan kepada masyarakat mengenai segalahal dalam melakukan tahapan proses maupun biaya adminisratif. Transparansi juga merupakan salah satu acuan dalam good governance. Adanya transparansi dalam penyelenggaraan pemerintahan dan pembuatan kebijakan dapat menjadi entery point bagi masyarakat untuk mendapatkan informasi sehingga dapat melakukan check and balance terhadap jalannya pemerintahan. Sejalan dengan pemaparan di atas, berikut ini 
merupakan hasil dari wawancara dengan bapak Dudi Rukandi sebagai Kepala Seksie Pengujian Kendaraan Bermotor di Dinas Perhubungan Kabupaten Subang mengenai transparansi pogram : "Transparansi program di Dinas Perhubungan Kabpuaten Subang menurut saya sudah sangat transparan semua sudah lengkap dan mengeahui tentang program yang telah uji layak kendaraan di kantor ini dan sudah ada lengkap tahapan proses yang harus dilalui oleh kendaraan yang sedang di uji. maupun tahapan pelaksanaan dari awal hingga akhir semuanya sudah sangat terbuka bagi siapapun yang melakukan Uji layak kendaraan". Dari hasil wawancara di atas peneliti dengan Kepala Seksie bidang Pengujian Kendaraan Bermotor berkala Dinas Perhubungan Kabupaten Subang, transparansi di sini sudah di terapkan dan sudah berjalan dengan efektif dan efisien diihat dari aspek-aspek sarana dan prasarana yang telah di terapkan/dipasang di Dinas Perubungan Kabupaten Subang. Berikut ini merupakan hasil wawancara dengan bapak Deni Setiawan selaku Staf Pengujian Kendaraan Bermotor berkala di Dinas Perhubungan Kabupaten Subang mengenai keterbukaan sarana dan prasaana: “Upaya transparansi sarana dan prasarana sudah dilaksanakan di Dinas Perhubungan dengan telah di fasilitasinya bank BJB untuk pemohon KIR melakukan pembayaran langsung ke bank, jadi ada MOU. Dengan adanya sarana dan prasarana untuk melengkapi pembayaran akan mempersempit korupsi sekala kecil maupun sekala besar dan pendapatan langsung masuk ke Pendapatan Asli Daerah (PAD)". Dari hasil wawancara di atas peneliti dengan masyarakat atau pemohon uji layak kendaraan (KIR) mengenai program Pengujian Kendaraan Bermotor di Dinas Perubungan Kabupaten Subang, program yang diterapkan untuk masyarakat oleh Dinas Perhubungan Kabupaten Subang sudah terbilang cukup baik bisa kita lihat dari jumlah pemohon KIR yang semakin bertambah setiap tahunya, maka sosialisasi mengenai program Pengujian Kendaraan Bermotor bisa dikatakan berhasil. Berikut hasil wawancara dengan bapak Asan Kusnadi selaku masyarakat. Berdasarkan hasil wawancara dan pengamatan langsung di lapangan, pneliti dapat menyimpulkan usaha untuk membuat membuat transparansi program Pengujian Kedaraan Bermotor efektif memang sudah banyak diterapkan dari hal sosialisasi, sarana dan prasarana maupun transparansi dalam administratif sehingga konsep pelayanan menurut Sinambela (2010:5) tedapat 6 indikator yang mengacu pelayanan bisa di katakan baik salah satunya transparansi sudah bisa dikatakan baik. Efektivitas pelayanan Pengujian Kendaraan Bermotor berkala di Dinas Perhubungan Kabupaten Subang sudah menerapkan transparansi yang baik dilihat dari aspek terteranya papan pengumuman biaya, langsungnya pembayaran melalui bank BJB terbukanya proses uji layak berkendara dari semua bagian-bagian tersebut Pengujian Kendaraan Bernotor dalam transparansi dapat dikatakan efektif.

Hasil kajian terhadap kriteri "Akuntabilitas" dapat dejlaskan sebagai berikut : bahwa Akuntabilitas adalah pertanggungjawaban pengelolaan sumber daya 
serta pelaksanaan kebijakan yang dipercayakan kepada entitas pelaporan dalam mencapai tujuan yang telah ditetapkan secara agenda. Akuntabilitas publik yang dilakukan organisasi sektor publik terdiri atas empat dimensi akuntabilitas yang mesti dipenuhi organisasi sektor publik (Ellwood, 1993).

1) Accountability for probity and legality, akuntabilitas kejujuran dan hukum. Akuntabilitas hukum terkait dengan kepatuhan terhadap hukum dan peraturan yang diterapkan.

2) Process accountability, akuntabilitas proses. Akuntabilitas proses terkait dengan apakah prosedur yang digunakan dalam melaksanakan tugas sudah cukup baik dalam hal kecukupan sistem informasi akuntansi, sistem informasi manajemen, dan prosedur administrasi. Akuntabilitas ini diterjemahkan melalui pemberian pelayanan publik yang cepat, responsif, dan murah biaya. Pengawasan dan pemeriksaan dapat dilakukan terhadap akuntabilitas proses, untuk dapat menghindari kolusi, korupsi dan nepotisme.

3) Program accountability, akuntabilitas program, untuk pertimbangan apakah tujuan yang ditetapkan dapat tercapai, dan apakah ada alternatif program lain yang memberikan hasil maksimal dengan biaya minimal.

4) Policy acounttabillity, akuntabilitas kebijakan, terkait dengan pertanggungjawaban pemerintah atas kebijakan yang diambil terhadap DPR/DPRD dan masyarakat luas.

Akuntabilitas merupakan pertanggungjawaban atas proses atau tindakan yang telah kita perbuat untuk manapun. Berikut ini adalah hasil wawancara peneliti dengan bapak Dudi Rukandi sebagai Kepala Seksie Pengujian Kendaraan Bermotor Dinas Perhubungan Kabupaten Subang mengenai akuntabilitas pelaksanaan program PKB : "dalam akuntabilitas yang beararti pertanggungjawaban kami telah menjalankan semua ketentuan berdasarkan Standar Oprasional Prosedur yang ada di Dinas Perhubungan Kabupaten Subang bidang Pengujian Kendaraan Bermotor. Semua proses proses dan tahapan yang staf lalui sebisa mungkin harus berdasarkan aturan agar proses dan tujuan bisa efektif dan efisien". Berdasarkan hasil wawancara diatas peneliti dengan Kepala Seksie bidang Pengujian Kendaraan Bermotor di Dinas Perhubungan Kabupaten Subang dapat disimpulkan berarti pertanggungjawaban atau akuntabilitas disini sudah di laksanakan dengan sebaik mungkin karena dilihat dari Standar Oprasional Prosedur (SOP) yang sudah staf dan petugas lakukan setiap harinya kepada pemohon uji layak kendaraan (KIR). Selanjutnya peneliti mewawancarai bapak Deni Setiawan sebagai staf Pengujian Kendaraan Bermotor mengenai akuntabilitas dalam sarana dan prasarana : "akuntabel sarana dan prasarana sudah kami lakukan berdasarkan aturan dan ketentuan, dalam segi pemeriksaan mesin peralatan untuk menguji kami rutin bersihkan dan periksa kelayakan fungsinya agar beroprasional dengan baik ketika sedang di oprasikan". Berdasarkan hasil wawancara peneliti di atas dengan staf Pengujian Kendaraan Bermotor di Dinas 
Pehubungan Kabupatern Subang mengenai akuntabilitas sarana dan prasarana memang akuntabel dalam sarana dan prasarana sudah dilakukan sesuai dengan prosedur yang ada dan setiap jam pulang kerja mesin peralatan di bersihkan dan di bungkus terpal agar menghindari dari kerusakan-kerusakan yang di akibatkan oleh alam seperti cipratan air hujan di malam hari dan banyak hal lainya. Selanjutnya peneliti mewawancarai bapak Ricko Fadilah sebagai staf administrasi mengenai akuntabilitas pelaksana program : "akuntabilitas pelaporan program Pengujian Kendaraan Bermotor sudah kami lakukan dengan membuat laporan pembukuan perhari perbulan dan di rekup di ahir tahun untuk mengetahui peningkatan atau penurunan angka kendaraan yang masuk uji KIR pertahunya". Berdasarkan hasil wawancara peneliti diatas dengan staf administrasi yang membuat laporan akuntabilitas dalam pelaksanaan program sudah dilakukan dengan baik dapat kita lihat dari bentuk pendataan jumlah kendaraan yang masuk perhari, jenis kendaraan dan uji kendaraan baru di KIR maupun berkala yang berkelanjutan, dari hasil laporan itu makan akuntabilitas pelaksanaan program sudah dilaksanakan dengan baik. Berdasarkan hasil wawancara dan pengamatan langsung di lapangan, pneliti dapat menyimpulkan upaya untuk mencapai akuntabilitas di Pengujian Kendaraan Bermotor di Dinas Pehubungan Kabupaten Subang sudah bisa dikatakan mencapai angka baik meskipun ada beberapa petugas pengujian yang belum menerapkasn sistem senyum, sapa, sopan dan salam akan tetapi pada keseluruhan bisa dikatakan baik. Sehingga konsep pelayanan menurut Sinambela (2010:5) tedapat 6 indikator yang mengacu pelayanan dapat dikatakan baik yaitu salah satunya akuntabilitas sudah baik. Hal tersebut bisa di lihat dari pengoprasionalan alatalat pengujian kendaraan bermotor, datangnya langsung ke lokasi kejadian kecelakaan bilamana ada kecelakaan angkutan umum yang di sebabkan oleh kerusakan teknis, pembersihan dan perawatan kembali alat-alat uji dan sarana prasarana. berikut :

Hasil kajian terhadap kriteria "Kondisional" dapat dijelaskan sebagai

Kondisional adalah suatu keadaan dimana penyesuaian dengan kondisi yang sedang di alami sesuai dengan kondisi dan kemampuan pemberi dan penerima pelayanan dengan tetap berpegang pada prinsip efisiensi dan efektifitas. Berikut hasil kutipan wawancara peneliti dengan bapak Dudi Rukandi sebagai Kepala Seksie Pengujian Kendaraan Bermotor mengenai kondisi yang berpgang pada efektiv dan efisien : "pengujian kendaraan bermotor mengenai efektif dan efisien sesuai dengan kondisi sekarang memang masih belum sepenuhnya berhasil. Dapat dilihat dari kondisi waktu yang tertera di billboard yang seharusnya 25 menit berikut dengan administrasi tetapi masih ada dan lumanyan banyak yang melebihi waktu tersebut. Keterlambatan bisa dikarenakan faktor teknis maupun faktor kerusakan kendaraan." Berdasarkan hasil wawancara peneliti diatas dengan Kepala Seksi bidang pengujian kendaraan bermotor mengenai kondisi yang berpegang pada efektif dan efisien. Keterlambatan atau kesesuaian waktu 
tergantung kondisi yang ada disana karena banyak terdapat masalah ketika pengujian sang berlangsung mayoritas kesalahan terdapat di kendaraan yang sedang di uji. Berdasarkan hasil pengamatan langsung di lapangan kondisional dapat dikatakan baik tetapi masih banyak catatan yang harus Dinas Perhubungan Kabupaten Subang perbaiki mengenai kurangnya kemampuan petugas Pengujian Kendaraan Bermotor dalam memperbaiki masalah kerusakan mesin atau alat-alat uji yang ada di gedung pengujian. Sehingga konsep pelayanan menurut Sinambela (2010:5) tedapat 6 indikator yang mengacu pelayanan dapat dikatakan efektif yaitu salah satunya Kondisional yang belum baik. Hal ini bisa dilihat dari kurangnya kemampuan petugas untuk memperbaiki mesin atau alat-alat untuk menguji jika dimana adanya kerusakan. Harus selalu memanggil tenaga ahli untuk memperbaiki sehingga bisa mengurangi pemasukan untuk Dinas Perhubungan tersebut.

Hasil kajian terhadap kriteria "Partisipasi" dapat dijelaskan sebagai berikut : Partisipasi berasal dari bahasa inggris yaitu "participation" adalahpengambilan bagian atau pengikutsertaan. Menurut Keith Davis, partisipasi adalah suatu keterlibatan mental dan emosi seseorang kepada pencapaian tujuan dan ikut bertanggung jawab di dalamnya. Dalam defenisi tersebut kunci pemikirannya adalah keterlibatan mental dan emosi. Sebenarnya partisipasi adalah suatu gejala demokrasi dimana orang diikutsertakan dalam suatu perencanaan serta dalam pelaksanaan dan juga ikut memikul tanggung jawab sesuai dengan tingkat kematangan dan tingkat kewajibannya. Partisipasi itu menjadi baik dalam bidang-bidang fisik maupun bidang mental serta penentuan kebijaksanaan. Jadi dari beberapa pengertian di atas, maka dapat ditarik kesimpulan bahwa partisipasi adalah keterlibatan mental dan emosi serta fisik peserta dalam memberikan respon terhadap kegiatan yang melaksanakan dalam proses belajar mengajar serta mendukung pencapaian tujuan dan bertanggung jawab atas keterlibatanya. Berikut hasil kutipan wawancara peneliti dengan bapak Dudi Rukandi sebagai Kepala Seksie Pengujian Kendaraan Bermotor mengenai pencapaian aspek aspirasi masyarakat : "mengenai aspek aspiasi masyarakat kami belum memperhatikan aspek itu karena kami belum mengadakan rapat tebuka yang mengundang seluruh stakeholder dan masyarakat untuk menyampaikankan pendapatnya melalui rapat tersebut. Kemungkinan besar kami akan adakan hal seperti itu". Berdasarkan hasil wawancara peneliti diatas dengan Kepala Seksie Pengujian Kendaraan Bermotor mengenai pencapaian aspek aspirasi masyarakat memang belum diadakanya rapat terbuka dengan mengundang seluruh stakeholder dan masyarakat mengenai pengujian kendaraan bermotor agar bagaimana pencapaian dan proses bisa saling lebih menguntungkan untuk pemberi dan penerima pelayanan. Berikut hasil wawancara peneliti dengan bapak Asan Kusnadi sebagai masyarakat mengenaik kesesuaian pelayanan dengan kebutuhan masyarakat : "menrut saya yang kita butuhkan dengan yang di berikan oleh intansi ini sudah cukup puas karena 
masyarakat tidak banyak meminta ini itu hanya saja mayoritas masyarakat ingin pelayanan cepat mudah dan murah tapi balik lagi ke kondisi kendaraan dan keadaan di gedung pengujian". adanya staf yang tidak ada di lokasi dalam jam kerja dan benar juga Dinas Perhubngan bidang Pengujian Kenaraan Bermotor belum mengadakanya rapat terbuka yang mengundang seluruh stakeholder dan masyarakat untuk menyampaikan aspirasi mengenai kebutuhan hasrapan yang masyarakat inginkan untuk membuat lebih saling menguntungkanya di pemberi pelayanan dan penerima pelayanan. . Sehingga konsep pelayanan menurut Sinambela (2010:5) tedapat 6 indikator yang mengacu pelayanan dapat dikatakan efektif yaitu salah satunya Partisipatif yang belum baik. Hal ini bisa dilihat dari Dinas Perhubungan Kabupaten Subang belum mengadaka rapat terbuka yang mengundang seluruh stakeholder dan masyarakat mengenai penyampaian aspirasi masyarakat untuk saling menguntungkanya antara penerima pelayanan dan pemberi pelayanan.

Hasil kajian terhadap dikriteria "Kesamaan Hak" dapat dikemukakan bahwa : Kesamaan Hak yaitu tidak diskriminatif dalam arti tidak membedakan suku, ras, dan agama, golongan, gender dan status ekonomi. Berikut hasil wawncara peneliti dengan Kepala Seksie bidang Pengujian Kendaraan Bermotor bapak Dudi Rukandi mengenai perlakuan adil dalam pelayanan : "adil dalam pelayanan menurut saya, saya pribadi sudah berlaku sangat adil bagi siapapun. Saya tidak membedakan dari segi status sosial maupun orang kaya. Saya perlakukan semua dengan sama begitupun di pengujian semua diperlakukan sama tidak ada perbedaan". Berdasarkan hasil wawancara peneliti diatas dengan Kepala Seksie Pengujian Kendaraan Bermotor mengenai perlakuan adil terhadap pemberi pelayanan mungkin memang Kepala Seksie sudah berlaku adil terhadap siapapun masyarakat yang sedang melakukan pengujian kendaraan bermotor namun kemungkinan ada oknum yang tidak bertanggung jawab menggunakan pungli sebagai mata pencaharian lebih akan tetapi Kepala Seksie tidak mengetahuinya. Berikut hasil wawancara peneliti dengan bapak Deni Setiawan selaku staf Pengujian Kendaraan Bermotor mengenai perbedaan pelayanan menurut status sosial : "saya melakukan proses pengujian kendaraan bermotor tidak ada yang di bedakan sama sekali semua saya layani berdasarkan prosedur dan aturan yang ada di Dinas Perhubungan. Kemungkinan ada saja yang membedakan pelaynan yang di berikan tetapi saya pribadi melakukan proses pengujian dengan sama rata". Berdasarkan hasil wawancara peneliti diatas dengan staf Pengujian Kendaraan Bermotor mengenai perbedaan pelayanan menurut status sosial para staf melaukan proses pengujian dengan memperhatikan prosedur dan aturan kemungkinan ada oknum yang memanfaatkan ketika masyarakat yang tidak tahu ketentuan dan persyaratan akan tetapi staf teknisi tidak mengeahuinya. Berikut hasil wawancara peneliti dengan bapak Ricko Fadhilah sebagai staf administrasi mengenai tindakan diskriminiasi non verbal dalam pelayanan : "diskriminasi non verbal menurut 
saya tidak ada. Karena semua saya layani dengan rata kecuali memang yang melalui perantara lebih di kedepankan dan memang cenderung lebih cepat ketika proses pengujian sedang berlangsung tapi perbedaaan antara yang melalui perantara dan yang langsung hanya berbeda sedikit yaitu dalam proses pengujian sedang berlangsung". Berdasarkan hasil pengamatan langsung dilapangan dalam pengujian kendaraan bermotor perantara menang di unggulkan dan tidak bisa di pungkiri ini sudah menjadi rahasia umum dimana yang mempunya status sosial tinggi, uang yang lebih dan mempunyai orang dalam akan relatif lebih cepat namun biaya bisa cenderung lebih mahal. Sehingga konsep pelayanan menurut Sinambela (2010:5) tedapat 6 indikator yang mengacu pelayanan dapat dikatakan efektif yaitu salah satunya Kesamaan Hak, belum baik. Dapat dilihat dari perbedaan perbedaan diatas.

Selanjutnya berdasarkan kriteria "Keseimbangan Hak dan Kewajiban" dapat dijelaskan bahwa yang dimaksud adalah seimbangnya antara hak dan kewajiban dimana kita tidak boleh terus-menerus menuntut hak tanpa melakukan kewajiban kita dan tidak boleh terus menyuruh yang lain melakukan kewajibannya tanpa kita memberikan haknya. Berikut hasil kutipan wawancara peneliti dengan Kepala Seksie bapak Dudi Rukandi mengenai aspek keadilan bagi pemberi pelayanan : "mengeneai keadilan kami memperlakukan semua staf pegawai kami dengan sama dengan adil akan tetapi akan berbeda jika mereka yang berbeda jabatan karena saya selalu berusaha perlakukan adil untuk semua karyawan atau bawahan saya". Berdasarkan hasil wawancara peneliti diatas dengan Kepala Seksie Pengujian Kedaraan Bermotor mengenai aspek keadilan bagi pemberi pelayanan memang dalam pelakuan adil sudah di usahakan semaksimal mungkin akan tetapi perbedaan pasti akan terasa dengan perbedaan jabatan namun sebisa mungkin sebagai leader harus bisa berprilaku adil dalam memberikan tugas apapun kepada siapapun. Berikut hasil wawancara peneliti dengan bapak Deni Setiawan selaku staf Pengujian Kendaraan Bermotor mengenai aspek keadilan bagi penerima pelayanan : "perlakuan adil bagi penerima pelayanan sudah sangat saya utamakan karena memang sesuai dengan SOP dan saya sebisa mungkin akan berperilaku adil seadil-adilnya agat terjalin dan bisa menambah citra baik utuk Dinas Perubungan terutama bidang Pengujian Kendaraan Bermotor". Berdasarkan hasil wawancara peneliti diatas dengan staf pengujian mengenai aspek keadilan bagi penerima pelayanan sudah di terapkan untuk keadilan bagi penerima pelayanan mereka berpacu pada Standar Oprasional Prosedur yang ada. Akantetapi berbeda lagi jika mereka melakukan pendafataran pengujian yang melalui perantara, waktu yang lebih cepat namun pembayaran yang relatif lebih mahal. Berikut hasil wawancara peneliti dengan bapak Ricko Fadhilah sebagai staf administrasi mengenai keseimbangan hak dan kewajiban : "sudah sangat seimbang antara hak yang harus didapat dan kewajiban yang harus masyarakat penuhi sudah seimbang. Semua sudah pernah kami rundingkan antara hak dan kewajiban dan semuanya sudah kami lakukan untuh berupaya bagaimana caranya mengunggulkan hak 
yang harus mereka atau masyarakat dapakan". Berdasarkan hasil wawancara peneliti diatas dengan staf administrasi mengenai keseimbangan hak dan kewajiban staf Dinas Perhubungan sudah mengadakan perundingan sebelumnya yang nenbicarakan tentan hak dan kewajiban untuk pemohon KIR yang lebih di dominasikan semua pegawai staf Pengujian Kendaraan Bermotor sudah mengutamakan hak yang di dapat oleh pemohon KIR dan mereka tetap berpacu pada SOP. Selanjutnya peneliti mewawancarai bapak Syarif Nurjamin selaku masyarakat mengenai pertimbangan aspek keadilan bagi masyarakat : "menurut saya keadilan sudah sesuai dengan kewajiban yang harus kita keluarkan, semua sesuai dengan apa yang harus pemohon keluarkan, tergantung bagaimana kita dan kepada siapa kita akan membawa kendaraan tersebut". Berdasarkan hasil wawancara keseluruhan berdasarkan hasil wawancara yang saya rangkum keadilam yang sudah di lakukan oleh intansi sudah dapat memuaskan masyarakat dan harapan dilihat dari usaha yang mereka lakukan dengan merundingkanya terlebih dahulu sebelum pengujian kendaraan benar benar beropasi namun terdapat adanya perbedaan yang membedakan dalah segi waktu dan biaya yaitu pemohon KIR yang melalui perantara dan yang tidak melalui perantara. Berdasarkan hasil pengamatan langsung dilapangan memang benar keadilang yang sudah di berikan oleh Dinas Perhubungan sudah sesuai dengan apa yang kita keluarkan. Contoh nya jika kita mendaftar melalui perantara atau biro jasa kita akan mempercepat waktu proses pengujian dengan pengeluaran biaya yang cenderung lebih mahal begitu pula sebaliknya jika kita mendaftar langsung sendiri proses pengujian akan berjalan normal terlebih jika ada permasalahan dalam kendaraan, kendaraan tersebut biosa tidak lulus pengujian. Sehingga konsep pelayanan menurut Sinambela (2010:5) tedapat 6 indikator yang mengacu pelayanan dapat dikatakan efektif yaitu yang terakhirnya Keseimbangan Hak dan Kewajiban, sudah baik. Dapat dilihat dari keadilan yang masyarakat keluarkan dengan yang mereka dapatkan.

Efektivitas pengujian kendaraan bermotor di Dinas Perhubungan Kabupaten Subang salah satu pelayanan yang diberikan pemerintahan pusat melalui Dinas Perhubungan ke berbagai daerah yang berhubungan dengan administrasi, proses pengujian dan buku KIR hasil dari proses pengujian kenaraan yang mana keberlakuan buku KIR hanya berlaku selama enam bulan dan bilamana masa berlaku buku KIR sudah habis diharuskan kembali masyarakat untuk menguji kendaraanya kembali atau yang sering kita sebut Pengujian Berkala. Namun pemberi pelayanan tidak bisa semena-mena memberikan pelayanan tanpa adanya pemasukan dari masyarakat. Dalam hal ini berarti kesesuaian antara hak dan kewajiban sangat berperan dominan. Pelayanan yang efektif dapat dinilai dari dimensi-dimensi pelayanan sebagai berikut : Dimensi Transparansi, dimensi transparansi disini dimana keharusan keterbukaan apa yang seharusnya masyarakat mengetahui dan untuk dilengkapi keharusanya untuk memenuhi persyaratan sebelum pengujian kendaraan 
bermotor berlangsung. Keterbukaan disini juga bukan hanya dalam prihal persyaratan namun juga dalam hal rincian biaya pengluaran yang man aharus masyarakat keluarkan untuk bisa masyrakat mengetahui patokan keharusan yang harus mereka keluarkan. transparansi juga bukan hanya di Dinas Perhubungan bagin Pengujian Kendaraan Bermotor saja, Transparansi juga merupakan salah satu pilar dalam good governance. Adanya transparansi dalam penyelenggaraan pemerintahan dan pembuatan kebijakan dapat menjadi entery point bagi masyarakat untuk mendapatkan informasi sehingga dapat melakukan check and balance terhadap jalannya pemerintahan. Sesuai dengan apa yang dikemukakan oleh Sinambela (2010:5) mengenai Transparansi, transparansi yang ada di Dinas Perhubungan Kabupaten Subang sudah diusahakan semaksimal mungkin dengan mengadakanya langsung bank BJB, papan pengumuman persyaratan, papan pengumuman rincian biaya, proses pelaksanaan pengujian sampai tahapan ahir pengecatan tanggal di bagian kendaraan dan penyerahan buku KIR. Jadi Transparansi di Dinas Perhubungan Kabupaten Subang bidang Pengujian Kendaraan Bermotor sudah eafektif.

Dimensi Akuntabilitas, akuntabilitas yang berarti pertanggung jawaban petugas teknisi maupun adminiatrasi sudah menerapkan pertanggung jawaban kepada setiap yang mereka lakukan. Petugas teknisi sudah bertanggung jawab dengan mengurus dan merawatnya peralatan untuk menguji kendaraan dengan sebelum jam kerja selesai mereka membersihkan kembali peralatan dan membungkusnya kembali agar alat pengujian menjadi lebih awet dan tahan lama. Bagian petugas administrasi mereka melakukan perekupan data untuk laporan bulanan dan tahunan yang di input dari kegiatan pemasukan seharihari. Akuntabilitas juga berperan sangat penting bagi good governance. Bentuk pertanggungjawaban tersebut berbeda satu dengan lainnya tergantung dari jenis organisasi yang bersangkutan. Instrumen dasar akuntabilitas adalah peraturan perundang-undangan yang ada, dengan komitmen politik akan akuntabilitas maupun mekanisme pertanggungjawaban, sedangkan instrumen-instrumen pendukungnya adalah pedoman tingkah laku dan sistem pemantauan kinerja penyelenggara pemerintahan dan sistem pengawasan dengan sanksi yang jelas dan tegas.

Dimensi Kondisional, kondisional ini berdasarkan kondisi kenyataan di lapangan langsung, kondisional di Dinas Perhubungan Kabupaten Subang memang sudah tercukupi karena kondisional disini keharusan ketika pengujian sesuai dengan kondisi SOP yang ada dan kondisional pada pelayanan sudah diterapkan oleh seluruh pegawai yang baik.Sesuai dengan apa yang telah dikemukakan oleh Sinambela (2010:5) mengenai Kondisional, kondisional yang sudah diterapkan oleh Dinas Perhubungan Kabupaten Subang sudah baik karena mereka berpacu kepada SOP yang ada dan mereka sudah melayani pemohon KIR dengan sesuai aturan bilamana ada kendaraan yang belum memenuhi kriteria. Dimensi Partisipatif, dimensi partisipatif disini semua ikut serta ikut andil dalam mewujudkan pelayanan yang baik dan efketif. 
Keikutsertaan keseluruhan di Dinas Perhubungan Kabupaten Subang belum sepenuhnya merata hal ini bisa dilihat dari Dinas Perhubungan Kabupaten Subang bidang Pengujian Kendaraan Bermotor belum mengadakan rapat yang mengundang seluruh masyarakat dan stakeholder untuk merundingkan dan menyampaikan keluhan dan aspirasi masyarakat beserta stakeholder agar Pengujian Kendaraan Bermotor bisa beroprasi dengan saling menguntungkan juga efektif dan efisien.Ketidak sesuaian dengan apa yang telah dikemukakan oleh Sinambela (2010:5) mengenai Partisipatif, partisipatif di Dinas Perhubungan Kabupaten Subang bidang Pengujian Kendaraan Bermotor belum sepenuhnya berpartisipasi dengan baik bisa dilihat dari belum mengadakanya rapat yang mengundang seluruh stakeholder dan masyarakat mengenai pencapaian pelayanan yang baik juga efektif dan efisien. Dimensi Kesamaan Hak, kesamaan hak disini mereka mendapatkan perlakuan pelayanan yang sama tanpa di bedabedakan tidak diskriminatif dalam arti tidak membedakan suku, ras, dan agama, golongan, gender dan status ekonomi dan status sosial. Pemohon KIR harus mendapatkan pelayanan yang sama dari pemberi pelayanan. Ketidak sesuaian dengan apa yang telah dikemukakan oleh Sinambela (2010:5) mengenai Kesamaan Hak, perbedaan hak yang didapat oleh masyarakat biasa dengan masyarakat yang mempunyai status sosial yang tinggi merupakan salah satu penyebab ketidak samaan hak dan kewajiban artinya perbedaan yang di rasakan oleh masyarakat mengenai status sosial dan orang dalam. Dimensi Keseimbangan Hak dan Kewajiban, keseimbangan disini merupakan seimbangnya antara apa yang dikeluarkan oleh pemohon KIR dengan hak yang seharusnya mereka dapatkan yang berati masyarakat memenuhi persyaratan dan melakukan pembayaran untuk menguji kendaraanya dan mereka ber hak mendapatkan hasil dari uji kendaraan tersebut seperti pelayanan yang baik sopan, buku KIR, pengencatan pada bagian kendaraan mengenai tanggal habisnya masa berlaku KIR. Dan juga di Dinas Perhubungan Kabupaten Subang bidan Pengujian Kendaraan Bermotor dimana ada kendaraan yang akan di uji milik seseorang yang mempunyai status sosial yang tinggi, kendaraan tersebut milik salah satu teknisi penguji kemungkinan besar proses pengujian akan relatif lebih singkat karena mereka memiliki pengaru terhadap kesamaan hak. Tidak sesuai dengan apa yang telah dikemukakan oleh Sinambela (2010:5) mengenai Keseimbangan Hak dan Kewajiban, msyarakat seharusnya mendapatkan perlakuan pelayanan yang sesuai dengan yang mereka keluarkan. Artinya masyarakat membayar biaya memenuhi persyaratan langsung atau melalui perantara dan masyarakat yang mempunyai status sosial tinggi semua itu seharusnya diberikan pelayanan yang sama karena mereka sama-sama memenuhi kewajiban untuk mendapatkan haknya yang mereka harapkan. 


\section{Kesimpulan}

Berdasarkan hasil penelitian dan pembahasan yang telah dikemukakan pada bab sebelumnya, peneliti mengambil kesimpulan bahwa efektivitas pengujian kendaraan bermotor berkala di Dinas Perhubungan Kabupaten Subang belum sepenuhnya efektif yang mengarah pada teori pelayanan yang dikemukakan oleh Sinambela, hal ini dilihat dari adanya 3 (tiga) dimensi yang belum efektif dan (tiga) 3 dimensi yang sudah efektif. Untuk leibh jelasnya bisa dilihat sebagai berikut:

a) Transparansi di Dinas Perhubungan Kabupaten Subang sudah di terapkan dengan baik, hal ini bisa dilihat dari terteranya papan pngumuman (billboard) mengenai persyaratan, rincian pembayaran, waktu pengujian dan penyediaan fasilitas bank BJB yang ada di dalam lingkungan kantor Dinas Perhubungan.

b) Akuntabilitas di Dinas Perhubungan Kabupaten Subang sudah di terapkan dengan baik, hal ini dapat dilihat dari pengoprasionalan peralatan pengujian yang dikuasai oleh petugas yang memiliki lisensi teknisi, petugas pengujian langsung datang ke Tempat Kejadian Perkara bilamana ada terjadi kecelakaan angkutan kendaraan maupun angkutan barang, petugas membersihkan kembali peralatan pengujian ketika jam kerja sudah selesai.

c) Kondisional di Dinas Perhubungan Kabupaten Subang belum diterapkan dengan baik. Hal ini dapat dilihat dari ketidak mampuan petugas teknisi untuk memperbaiki bilamana ada peratlatan pengujian yang rusak petugas tidak bisa memperbaikinya hanya bisa mengoprasionalkanya, pihak Dinas Perhubungan harus memanggil tenaga ahli untuk memperbaiki kerusakan alat pengujian.

d) Partisipasi masyarakat dan seluruh stakeholder untuk menyampaikan aspirasinya mengenai pelayanan Pengujian Kendaraan Bermotor yang mana nantinya timbul sebuah saling menguntungkanya antara pemohon dan pemberi dengan mengadakan rapat terbuka.

e) Kesamaan Hak di Dinas Perhubungan Kabupaten Subang belum di terapkan dengan baik. Hal ini dapat dilihat dari perbedaan pelayanan yang melalui perantara dan pemohon yang mendaftar langsung, perbedaan pelyanan menurut status sosial dan perbedaan pelayanan yang di berikan bilamana ada kendaraan angkutan milik pegawai teknisi.

f) Keseimbangan Hak dan Kewajiban di Dinas Perhubungan Kabupaten Subang sudah di terapkan dengan baik. Hal ini dapat dilihat dari sesuainya antara yang harus dikeluarkan oleh pemohon KIR dengan apa yang mereka dapatkan hak nya, berarti sudah sesuainya antara yang dikeluarkan oleh pemohon yang melalui perantara dengan biaya yang mahal tetapi waktu pengerjaan yang relatif singkat. Sebaliknya pemohon yang mendaftar tidak melalui perantara dengan biaya yang sesuai dan proses yang seadanya. 


\section{Referensi}

Creswell, J.W. 2010. Research Design: Pendekatan Kualitatif, Kuantitatif, dan Mixed. Bandung: Pustaka Pelajar

Dr.Nuasa Putra, 2013, metode penelitian kualitatif manajemen, PT. Raja Grafindo Persada, Jakarta

Georgopolousdan Tannembaum, 1985. Efektivitas Organisasi, Jakarta: Erlangga

Gibson, Jamaes L 2005. Transformasi Pelayanan Publik, Jakarta: Erlangga

Harbani Paslong, 2013, Teori Administrasi Publik, Bandung: Alfabeta Kasmir, 2005 etika kostumer servis, Jakarta : PT. Raja grafindo bersada

Keputusan Menteri Pendayagunaan Aparatur Negara No.63/KEP/M.PAN/7/ 2003.

Margaretha, 2004 kualitas pelayanan dan aplikasi, Bandung: Mundur Maju

Martini dan Lubis, 1987, teori organisasi, Bandung : Ghalia Indonesia

Moelong Lexy, 2007, metode penelitian kualitatif, Bandung: PT. Remaja Rosada

Mukarom, Zaenal dan Muhibudin Wijaya Laksana, Manajemen Pelayanan Publik.

Bandung : CV Pustaka Setia, 2015

Peraturan Mentri Perhubungan No. 98 Tahun 2013 tentang Standar Pelayanan Minimal (SPM) Angkutan orang

Peraturan Daerah Kabupaten Subang No.05 Tahun 2012 tentang Retribusi Jasa Umum

Richard M Steers, efektivitas organisasi (kaidah dan prilaku) Jakarta : Erlangga 1985 (jilid II)

Ridwan, Juniarso dan Sodik Sudrajat, achmad. 2009. Hukum Administrasi Negara dan Kebijakan Pelayanan Publik. Bandung: Nuansa

Siagian S.P, 1982, manajemen modern, Jakarta : Gunung Agung

Sinambela, Poltak Lijan 2010, reformasi pelayanan publik teori kebijakan dan implementasi, Jakarta PT. Bumi Aksara

Scott M. Cutlip, 2009, effective public relations, Edisi Kesembilan, cetakan ke-3, PT. Dian Rakyat, Jakarta

Sudarwan Danim, 2012, motivasi kepemimpinan dan efetivitas kelompok, PT. Rineka Cipta Jakarta perkantoran Mitra Mataram

Sugiyono, 2013. Metode Penelitian Administrasi. Bandung: CV. Alfabeta

The Liang Gie, 2002, ensiklopedia administrasi, Jakarta : PT. Gunung Agung

Undang-Undang No. 22 Tahun 2009 tentang Lalu Lintas \& Angkutan Jalan

Undang-undang Republik Indonesia pasal 1 nomor 25 tahun 2009 tentang Pelayanan Publik. 